\title{
DETERMINATION of MOTIVATION Muzakki PAYING ZAK at ZAKAT MANAGEMENT Institution (Case study on MSME owners)
}

\author{
Nurkholis'; Prabowo Yudo Jayanto ${ }^{2}$ \\ Department of Accountancy, Economics Faculty, State University of Semarang L2 Building, Sekaran \\ Gunungpati Campus, Semarang, Central Java 50229, Indonesia. \\ 1nkholis246@gmail.com; ${ }^{2}$ yudho@mail.unnes.ac.id
}

Received: $12^{\text {th }}$ September 2019 / Revised: $28^{\text {th }}$ November $2019 /$ Accepted: $7^{\text {th }}$ March 2020

\begin{abstract}
This study aims to test and analyze factors that influence the motivation of Muzakki to pay zakat through religiosity, understanding of zakat, level of income, environmental, accountability of zakat management agency and socialization of zakat management agency. The population in this research is all Muslim SMEs in Semarang, while 100 Muslim SME owners in Semarang that are randomly sampled. Data is collected using the questionnaires and analyzed using Structural Equation Modeling (SEM) and Partial Least Square (PLS) with Smart analysis tool PLS 3.0. The study shows that religiosity, understanding of zakat, income level, environment, and accountability of the zakat management agency has a positive and significant influence on the motivation of Muzakki to pay Zakaah. While socialization of zakat management zakat has no significant effect.
\end{abstract}

Keywords: Zakat, Motivation to pay zakat, SME

\section{INTRODUCTION}

Zakat is the fourth pillar of Islam that has the peace and privileges of the great potential in assisting the economy of the people. Zakat is an obligation for every Muslim who can afford and, in every sustenance, that someone has gained the rights of others. According to Satrio \& Siswantoro (2016), Zakat is one of the pillars of Islam that must be shown for the property of an individual whose terms are governed by certain rules that are guided in the Qur'an and hadith. In addition to running orders from Allah SWT according to the Qur'an, in terms of economic and social zakat is also expected to help overcome the problems of poverty and social welfare.

Law No. 23 of 2011 on Zakat Management aims to allow the organization of Zakat manager,
Infaq and alms can perform its functions properly according to the rules of religion and state. The Law of Zakat governs the organization that manages Zakat, Infaq, and alms under the national Amil Zakat Agency (Baznas), this institution is authorized to manage zakat nationally. The organization of Zakat management has the obligation to report every activity in the implementation of the collection, distribution, and utilization of zakat that has been audited to BAZNAS periodically.

Micro Small Enterprises (MSME) is the most effort done by the Indonesian people. MSME is an integral part of the business world and are the economic activities of the people who have the position, role and strategic potential to realize the structure of the national economy based on the Economic Democracy (Dawn, 
2016). MSME also has a strategic position, role, and potential in realizing job creation, income generation, economic growth and poverty reduction in Indonesia.

MSME's progress will not be realized if there is no government involvement, where the government is a bridge for micro-enterprises that need to develop their business by providing loans and business, management and bookkeeping training. Judging by the SME's contribution to the economic development of the nation, it is appropriate for the sharia institution to empower businessmen, one of them through Zakat management Agency, Infaq and Sadaqah. LAZ and BAZ are the management organization of zakat which part or all of the funds are sourced from public donations in the form of Zakat, Infaq, Shadaqoh, and Waqf.

Head of Baznas of Semarang City of the Great Andrarasmara (Baznas Semarang, 2018) said that about 70-80 percent of the Zakat fund in Semarang city came from civil servants. Baznas will do the improvement and try a number of breakthroughs to maximize the potential of zakat in the private sector. The potential of zakat in Semarang reached Rp 150 billion, but in 2016 Baznas of Semarang City only raised zakat of about Rp 3.5 billion. The low motivation of Muzakki from the private sector to pay zakat is due to the lack of understanding of zakat among the private parties and young children. Based on the explanation above, it can be concluded that the low motivation among private zakat is a lack of socialization among private charity. The government's step to do the improvement in conducting socialization is expected to foster the motivation of private parties to pay zakat.

There are mixed results of previous research related to the payment of zakat. Research conducted by Satrio \& Siswantoro (2016) found that income, trust, and religiosity have a significant influence on the motivation of Muzakki Berzakat through the institution of Amil Zakat. The research conducted by Siddiq (2015) found that religiosity has no significant effect on the motivation Muzakki pay zakat in the institution of Amil Zakat. From these two previous studies, we can see that there is a difference from the research results of the factor religiosities.
Income level variables still contained inconsistencies from previous research results, research conducted by Halimah (2017) showed that income level has a positive and significant effect on the motivation of Muzakki to pay zakat, while other research conducted by Siddiq (2015) indicated that income level has no significant effect on the motivation of Muzakki to pay zakat.

The environment is one factor affecting one's attitudes and behavior, both within the neighborhood/community relationships and family environment. Previous research on the environment on the motivation of Muzakki to pays the zakat done Rahayu (2015) stating that the family is one variable that affects Muzakki 's motivation to pay Zakaah. The results of the Pangestu (2016) study found that public relations have no effect on the motivation of Muzakki to pay zakat. While the Fiqhany \& Prasetyo (2014) stated that public relations are the dominant variables in determining the intention of paying the ZIS funds on the Nurul Hayat Foundation of the Tuban branch.

The theory used in this study is Al-Wala's theory, it is the foundation of the faith of a Muslim to love and be loyal to his religion, by carrying out the worship that Allah has ordered through the Qur'an and the Hadith of the Prophet Muhammad SAW and keep away from all its prohibitions. Further attribution theory is the theory that explains a person's behavior is caused by a dispositional factor (inner or internal factor). As well as Shariah Enterprise theory It is a theory that explains that Allah is the center of everything and the center of the return of mankind and the universe.

\section{$\mathrm{H}_{1}$ : religiosity positive and significant influence on the motivation Muzakki pay zakat.}

Al-Wala ' theory (loyalty) can explain that a person's religiosity will emerge because of his loyalty to his religion where his LOVE for Allah SWT and the apostle made the commandment and away from all its challenges with Heartfelt. Zakat is a pillar of the fourth Islamic, where every believer has an obligation to do it for the perfection of his religion.

Research examining the influence of religiosity or the level of faith in the motivation to 
pay Muzakki zakat in the management agency Zakat (Pangestu \& Jayanto, 2017) the level of faith positively influential and significant to the motivation of Muzakki to pay Zakaah on the institution of Amil Zakat. This indicates that the higher the religiosity of a person will be a greater desire to execute the order and avoid all the prohibition of Allah SWT. Someone who has not paid Zakaah if his religiosity is high then it will appear consciousness to pay zakaah to carry out the pillars of Islam.

$\mathrm{H}_{2}$ : The understanding of Zakat has a positive and significant effect on the motivation Muzakki to pay zakat in the Zakat management agency.

The attribution theory states that behavior based on internal factors is a behavior that is in the control of that person or is consciously in action. A person's understanding of the obligation of zakat will affect someone who has not done so to pay zakat according to the rules applicable in Islam.

The results of previous research examining the understanding of Zakat, of Rizkia, Muhammad, \& Shabri (2014) stated that the understanding of zakat is positive and significant to the decision of Muzakki Pay Zakat in Sabang city. According to Pangestu \& Jayanto (2017), the knowledge of zakat has a positive and significant effect on Muzakki 's motivation to pay zakat in the Amil zakat institution. The two studies above proved that the understanding of a person about zakat triggers his consciousness to implement what Allah has ordered about the obligation to issue the rights of others who are still in his provision through the Zakat fund.

$\mathrm{H}_{3}$ : The income level of a person has a positive and significant effect on Muzakki 's motivation to pay zakat in the Zakat management institution.

According to the theory of income level articulating is one of the internal factors affecting the desire of one to pay Zakaah, the higher the income of a person then the primary need has been fulfilled then the motivation to share with fellow The higher, in this case, pay zakaah for the obligation of someone who can afford to share with his neighbor according to the command of Allah SWT.
Previous research has examined the influence of income on the motivation of Muzakki to pay zakat at the Amil Zakat Institution of one of Satrio \& Siswantoro (2016) who said that the influential income Positive and significant to the motivation of Muzakki to pay zakat in the institution of Amil Zakat. Through the explanation above the researcher concluded that the greater the income received by a person will encourage the desire in order to help his brother who is less economically in terms, so the motivation appears to share through Zakat.

$\mathrm{H}_{4}$ : Environmental positive and significant effect on the motivation of Muzakki to pay zakat in the Zakat management agency.

Attribution theory can explain the environmental influence of a person's attitude because the environment is an external factor that directly relates to shaping a person's attitude so that the motivation arises to do something. The better the environment of a person then the better the nature and behavior of a person, so that the motivation grows one to do the good in accordance with the command of Allah SWT and keep away from all his prohibition.

Previous research examining the environmental influence of either public relations or the family environment among the following: Fiqhany \& Prasetyo (2014) said that the community relationship is the most affect intention Muzakki to pay zakat, Infaq, Sadaqah on the foundation Nurul Hayat Branch of Tuban. Rahayu (2015) in the study entitled Factors determinant of the motivation to pay zakat to the institution gets the result that the family is one factor that affects the motivation of one to pay zakat to the institution Amil Zakat.

H$_{5}$ : Accountability has a positive and significant effect on Muzakki 's motivation to pay zakat in the Zakat management institution.

Sharia theory Enterprise explained that the form of human ACCOUNTABILITY to Allah SWT in carrying out its business activities must comply with the prevailing rules, both the rules of the Government and in accordance with the instructed and Forbidden by Allah SWT. The better the accountability of an institution so that people's trust in the institution will be higher, so it raises the interest of people to pay Zakaah in the 
management agency because it believes that the institution will run Its job well.

Pangestu \& Jayanto (2017) conducted a research on the influence of accountability on the motivation Muzakki to pay zakat in the institution of Amil Zakat to get the result that accountability affects the motivation Muzakki pays zakat in the institution of Amil Zakat.

$H_{6}$ : Socialization has a positive and significant effect on Muzakki's motivation to pay zakat in the Zakat management institution.

According to the theory of Socialism attribution conducted by the Zakat, Management Agency is an external factor that affects people to perform actions that are expected by socialization actors. The understanding gained by a person from socialization will give the motivation to act that is to pay zakat to the zakat management agency.

Fiqhany \& Prasetyo's (2014) research on the influence of advertising on the motivation Muzakki pay zakat in the institution of Amil Zakat gets the results that the advertising simultaneously affects the motivation Muzakki pay zakat in the institution of Amil Zakat.

\section{METHODS}

The population in this research is a whole selector of Muslim SMES in Semarang, while the samples used in this research are 100 SME owners who are Muslim in Semarang. The sampling method this research uses the Random Sampling Area method.

Dependent variable in the study is the motivation Muzakki to pay Zakat (Y), while for the independent variable is religiosity (X1), an understanding of Zakat (X2), income level (X3), Environment (X4), accountability Management Agency Zakat (X5), and socialization of Zakat management Agency (X6).

The data retrieval techniques in this research are conducted by providing questionnaires directly to the 100 Muslim owners of SME in Semarang. The analytical techniques used are validity testing, reliability test, and measurement model (Outer model), Structural model (Inner model). The data analysis methods in this study use Structural Equation Modeling (SEM) with
Partial Least Square (PLS) and analysis outsmarts 3.0

\section{RESULTS AND DISCUSSION}

The descriptive analysis of respondents in this study was used to provide a background description of respondents including gender, age of respondents, employment and education level. Descriptive analysis of respondents is presented in Table 2. The descriptive analysis of variables in the study aims to see the minimum value, maximum value, average value and criteria of each research variable. Descriptive analysis results of variables are presented in the Table 3.

Data quality testing is done with validity tests and reliability tests. Based on the test results Using smart PLS 3.0 It is known that the outer loading value of every the variable indicator is over 0.7 and THE AVE value of each variable is more than 0.5 , so this research instrument can be declared valid and ready to be used to retrieve the research data. Based on the results output smart PLS 3.0 can be known that the value of Cronbach's alpha and composite Reliability has a value greater than 0.7 , then the instruments of this research can be considered reliable and ready to be used to retrieve data.

This research uses data analysis with a Structural Equation Model (SEM) approach with the Smart PLS 3.0 program. The analysis of this data uses two stages, first, an analysis of the outer model and inner model. Researchers created this research model using the Program smart pls 3.0. Figure 1 is the Output smart PLS. The results of the hypotheses in the test are presented in Table 4.

The test results of the hypothesis of the study stated that the hypothesized one $\left(\mathrm{H}_{1}\right)$ was accepted, which is a positive and significant religiosity against the motivation of paying zakat in the institution Management of Zakat. The bootstrapping resampling test results show the value of the variable coefficient of religiosity parameter of 0.225 and the T-Statistic value of 3.161. The variable religiosity has a positive influence on endogenous variables because it is seen from the value of a positive-value efficiency parameter. While the T-Statistic value of this variable has a value higher than 1.98 (T-table) 
then the variable religiosity has a significant effect on the endogenous variables.

Religiosity has a positive and significant influence on the motivation Muzakki to pay zakat caused by a person's belief in the teachings of Islam that ordered his people to pay zakaah on property They have. As shown in the pillars of Islam and the Qur'an.

Al-Wala ' theory (Loyalty) describes 3 implementations of al-Wala ' attitude (loyalty) in the Islamic economic system namely, the implementation of Allah SWT, entities, and stakeholders. The form of loyalty of a Muslim to Allah SWT is to carry out his commandments and avoid his prohibition, religiosity affect the motivation Muzakki pay Zakaah because one Muslim will be motivated to pay Zakaah as a form of loyalty to Allah SWT, the logic of each person doing a duty commanded by God then the religiosity of a person will increase because when doing a person's obligation will feel calm, Quiet, and comfortable to do other activities, so that the motivation arises one to carry out the obligations commanded by Allah SWT. It is in line with $\mathrm{Al}$ Wala 'theory.

The results of this research in line with previous research from Satrio \& Siswantoro (2016) said that religiosity positively affects the interest of paying zakat through the institution of Amil Zakat. The decision of Muzakki and Muzakki to pay Zakaah is influenced by the religiosity of one who believes that paying zakat is the obligation of Muslims in accordance with the Islamic pillars. Religiosity or obedience of a person against religion makes a person have the motivation to carry out the required orders so that the consciousness arises to pay zakat for the person who is qualified to issue zakaah.

Hypothesis two $\left(\mathrm{H}_{2}\right)$ states that the understanding of Zakat has a positive relationship and a significant effect on the motivation Muzakki pay zakat in the management agency of Zakat is acceptable. The bootstrapping resampling test results using the smartPLS tool show the coefficient parameter value of 0.222 with $t$ statistic value of 2.604. The value of this variable coefficient parameter has a positive value indicating there is a positive relationship between a variable understanding of zakat and endogenous variables. This variable has a significant effect on endogenous variables, can be seen from t-statistic values higher than 1.98 (T-table).

The understanding of zakat is positive and significant towards the motivation of paying Muzakki due to his knowledge to make a person aware of his duty as Muslims to live the command of Allah SWT and avoid all Restriction.

The attribution theory explains the behavior of someone who is influenced by internal and external factors, the understanding of zakat is an internal factor that causes the motivation to pay zakat. The higher the understanding of zakat, the higher the motivation to pay zakaah.

The results of this research in line with the research of Pangestu (2016) which gets the result that the knowledge of zakat is a positive and significant influence on Muzakki's motivation to pay zakat. The knowledge of one's obligation as a religious believer is one of the motivations to pay zakaah on its property and possessions.

Hypothesis three $\left(\mathrm{H}_{3}\right)$ states that the income level has a positive and significant effect on the motivation Muzakki paying zakat is acceptable. The bootstrapping resampling test results in Smart PLS indicate that the coefficient parameter value is 0.408 and a t-statistic value of 3.600 . These results indicate that the income level variable has a positive relationship because the value of the coefficient parameter is positive. The t-statistic value greater than 1.98 (t-table) signifies that the income-level variable has a significant effect on endogenous variables.

The theory of the attribution explains the level of income as an internal factor affecting a person to commit an act of paying zakat because it is realized that paying zakat is a duty for Muslims who have property. While the Sharia theory Enterprise explains that the income level of a person is increasing then as a form of accountability as a MUSLIM to Allah SWT, the person pays zakaah on the property he acquired. The results of this research in line with the research of Halimah (2017) with the result that income has a dominant influence on the motivation to pay zakat. Income is an important factor for someone to decide to pay the Zakaah or not after weighing whether the income is already qualified must pay Zakaah. 
Hypothesis four $\left(\mathrm{H}_{4}\right)$ states that the environment has a positive and significant effect on the motivation Muzakki paying zakat is acceptable. The result of a test using Smart PLS shows the result that the coefficient parameter value is 0.247 which means the environment variable has a positive relationship because the coefficient parameter value is positive and value t-statistics of 2.604, the value has a value of more than 1.98 (t-table) hence environmental variables have a significant effect on endogenous variables.

The theory of the attribution can explain the relationship of the environment with the motivation Muzakki to pay zakat, where the environment is an external factor that affects a person to do an action. In this environment as an external factor, another person will be one of the factors that determine a person to pay zakat in accordance with his duty as a Muslim. The environment is a place to socialize someone both in the family and the surrounding environment, where one learns various things with what he felt when socializing, if the environment of someone good where people in the vicinity of the family and neighbors teach good things, then the possibility of someone to fulfill his obligation to pay zakat with the provisions that apply increasingly higher.

This result is consistent with the study from Fiqhany \& Prasetyo (2014) that the community relationship simultaneously affects the intention Muzakki. Muzakki pays zakat funds, Infaq, Sadaqah at Yayasan Nurul Hayat Tuban branch.

Hypothesis five $\left(\mathrm{H}_{5}\right)$ states that the accountability of the management agency of Zakat has a positive and significant effect on the motivation Muzakki pay zakat is acceptable. The test result using smartPLS shows a coefficient parameter value of 0.363 which means variables of the account of the Zakat Management board have a positive relationship to the endogenous variable, which can be seen from the value Coefficient parameters are POSITF. While the TStatistic value is 4.228 , the value is greater than 1.98 (T-table) which means that accountability variables have a significant influence on endogenous variables.

Sharia theory Enterprise explained that the form of human accountability to Allah SWT in carrying out its business activities must comply with the prevailing rules, both the rules of the Government and in accordance with the instructed and Forbidden by Allah SWT. The better the accountability of an institution so that people's trust in the institution will be higher, so it raises the interest of people to pay Zakaah in the Zakat management agency because it is convinced that the institution will run Its job well.

The results of the research in line with research from Rahayu, 2015 with the research results showing that the accountability of the Board of Zakat affects the motivation Muzakki to pay zakat to Zakat Institute.

Hypothesis six (H6) states that the socialization of the management board of Zakat has a positive and significant effect on Muzakki 's motivation to pay zakat is rejected. The test result of the socialization of the Zakat management agency showed the value of the coefficient parameter of 0.066 and the t-statistic value of 0.902. Although the results of the test variables socialization of zakat management institution has a positive relationship, can be seen from the value of the efficiency parameter that is positive value but judging by the value of T-Statistic has a value of less than 1.98 (T-table) that means the socialization variables of zakat management Agency has no significant effect on the motivation Muzakki pay zakat in the management agency Zakat.

The theory of the attribution can show that the socialization of the management agency of Zakat affects Muzakki 's motivation to pay zakat by providing information about the obligation of zakat and channeling more equitable zakat funds if Muzakki pays zakat through zakat management Agency to be an external factor that will affect one's behavior to pay Zakaah. The Research results in line with research conducted Sha'adi (2018) stating that socialization has no significant effect on public interest or Muzakki to pay Zakaah ON LAZIZNU City of Yogyakarta.

\section{CONCLUSION}

Based on the results of research and discussion, it can be taken compulsion as follows: Religiosities have a positive relationship and significant effect on motivation Muzakki 
pays zakat at zakat Management Agency, understanding about Zakat has a positive relationship and significant effect on the motivation Muzakki pays zakat in zakat Management Agency, level of income has a positive relationship and significant effect on the motivation Muzakki pays zakat at the institution The manager of the Zakat, L.A. A positive relationship and significant effect on the motivation Muzakki to pay zakat in the Management of zakat, a The ability of Zakat Management board has a positive relationship and significant effect on the motivation Muzakki pays zakat at the zakat Management institution, and socialization The Board of Zakat has a positive effect but not significant to the motivation Muzakki pays zakat at the zakat Management Agency.

Based on the results and discussion, the researcher concluded some suggestions as follows: Based on the limitations of the turnover information given by respondents so that variable measurements The income level cannot use the ratio scale and is limited to the use of the Likert scale, it is recommended that further research use more accurate measurements and nurture subsequent research making the instrument of each variable there is a negative statement to be able to control the outcome of respondents ' answers is not haphazardly answer.

\section{REFERENCES}

"Baznas" (2018). Baznas Semarang maximizes Zakat potential in private sector. https://baznas.semarangkota.go.id/v3/detail post/baznas-semarang-maksimalkanpotensi-zakat-di-sektor-swasta (quoted on August 15, 2019)

Fiqhany, M. R., \& Prasetyo, A. (2014). The influence of integrated marketing communication against the intention Muzakki pay Zakat, Infaq, Shadaqoh on Yayasan Nurul Hayat Tuban Branch. Journal of Sharia Economics.1 . (9), 661 673.https://e-

journal.unair.ac.id/JESTT/article/view/543 (downloaded March 23, 2019)
Hairudin, E. K. (2014). Shaping children's characters from home.Jakarta: Elex Media computindo

Halimah, N. (2017). The motivation to pay Zakat at Lembaga Amil Zakat, Infaq, and Shadaqoh Muhammadiyah (LAZISMU) Ngrombo. Journal of Personality and Social Psychology, 1 . (1), 1188 - 1197. https://doi.org/10.1111/j.14697610.2010.02280.x (Downloaded on 12 April 2019)

Pangestu, I. (2016). Analysis in the factors that affect the motivation Muzakki pay ZakatDI Institute of Amil Zakat in Semarang.Thesis. State University of Semarang

Pangestu, I., \& Jayanto, P. Y. (2017). Analysis in Factors Affecting Muzakki Motivation to Pay Zakat in Semarang City. 6 . (1), 94 103.HTTPS://JOURNAL.UNNES.AC.id/sj u/indek. PHP/AAJ/article/View/12614 (downloaded March 10, 2019)

Rizkia, R., Muhammad, A., \& Shabri, M. (2014). The influence of cultural factors, motivation, regulation and understanding of zakat on the decision of Muzakki pays Zakat Mal. Journal Study \& Accounttans Research, 7(I), 29 .https://jurnal.unsyiah.ac.id.TRA/article/vie w/10132 (Downloaded on 15 march 2019)

Sakula. (2015). The influence of socialization on public interest in using Sharia financial institutions services.Thesis. Muhammadiyah University of Yogyakarta.

Satrio, E., \& Siswantoro, D. (2016). Analysis of income factors, belief and religiusity in influencing Muzakki interest to pay Zakat income through. 1 22.HTTPS://ELIB.IBS.AC.ID/MATERI/PR OSIDING/NA\% 20XIX\% $20 \quad(19) \%$ 20Lampung\% 202016/paper/083/PDF (Downloaded on 15 April 2019)

Siddiq, H. A. (2015). The influence of zakat knowledge, income level, religion and trust 
to the organization of Zakat management towards the interest of paying Zakaah on the institution of Amil Zakat: (case study of Muzakki in the Faculty of Islamic Religion and the Faculty of Economics and business Universias Muhammadiyah Surakarta. Thesis. Muhammadiyah University of Surakarta.

Sha'adi, N. (2018). Socialization contribution of Lazis $\mathrm{Nu}$ Yogyakarta against Muzakki behavior in fulfilling Zakat. Thesis.Yogyakarta: Univeristy Indonesian Islamic 
Table 1. Variable Operational Definitions

\begin{tabular}{|c|c|c|c|}
\hline Variable & Definition & Indicator & Measurement \\
\hline $\begin{array}{l}\text { Dependent } \\
\text { variables: The } \\
\text { motivation of } \\
\text { Muzakki pays } \\
\text { zakat }\end{array}$ & $\begin{array}{l}\text { Factors that encourage a } \\
\text { person to have a desire to pay } \\
\text { zakat in the management of } \\
\text { Zakat }\end{array}$ & $\begin{array}{ll}\text { a. } & \text { Loyalty } \\
\text { b. } & \text { Gratitude } \\
\text { c. Income } \\
\text { d. Social } \\
\text { e. Procedure } \\
\text { f. Consequences } \\
\text { Pangestu \& Jayanto: 2017) }\end{array}$ & $\begin{array}{l}\text { Likert } \\
1-4 \\
\text { SS, S, KS, TS }\end{array}$ \\
\hline $\begin{array}{l}\text { Independent } \\
\text { variables: } \\
\text { Religiusitas }\end{array}$ & $\begin{array}{l}\text { The level of obedience of a } \\
\text { believer to Islam, the higher } \\
\text { the level of obedience of one's } \\
\text { religion then the more } \\
\text { obedient one of the } \\
\text { commandments and the } \\
\text { prohibition of Allah SWT }\end{array}$ & $\begin{array}{l}\text { a. Beliefs } \\
\text { b. Experiences/practices } \\
\text { c. Appreciation } \\
\text { d. Knowledge } \\
\text { (Satrio \& Siswantoro: 2016) }\end{array}$ & $\begin{array}{l}\text { Likert } \\
1-4 \\
\text { SS, S, KS, TS }\end{array}$ \\
\hline $\begin{array}{l}\text { Independent } \\
\text { variables: } \\
\text { Understanding } \\
\text { of Zakat }\end{array}$ & $\begin{array}{l}\text { SEA collects information } \\
\text { about good zakat through } \\
\text { material available in books } \\
\text { and people who know the ins } \\
\text { and outs of Zakat, then from } \\
\text { the information gathered } \\
\text { combined with experience and } \\
\text { observation make a thorough } \\
\text { understanding of zakat, both } \\
\text { understanding, legal basis, } \\
\text { barriers of property that is } \\
\text { required to be declared, and } \\
\text { objects that must be Paid } \\
\text { Zakaah. }\end{array}$ & $\begin{array}{l}\text { a. Zakat Sense } \\
\text { b. Zakat Obligation } \\
\text { c. The legal basis of zakat } \\
\text { d. Ordinances of charity } \\
\text { e. Zakat Calculation } \\
\text { Pangestu \& Jayanto: 2017) }\end{array}$ & $\begin{array}{l}\text { Likert } \\
1-4 \\
\text { SS, S, KS, TS }\end{array}$ \\
\hline $\begin{array}{l}\text { Independent } \\
\text { variables: } \\
\text { Income Level }\end{array}$ & $\begin{array}{l}\text { Adding on the property that a } \\
\text { person has acquired from an } \\
\text { activity that relates to the other } \\
\text { party, whether the salary of a } \\
\text { person who works for another } \\
\text { person is the benefit that } \\
\text { someone has gained for } \\
\text { buying and selling goods or } \\
\text { services with Other parties }\end{array}$ & $\begin{array}{l}\text { a. Achieving Nisab } \\
\text { b. Own Ownership } \\
\text { c. Knowing the objects of } \\
\text { zakat } \\
\text { (Halimah: 2017) }\end{array}$ & $\begin{array}{l}\text { Likert } \\
1-4 \\
\text { SS, S, KS, TS }\end{array}$ \\
\hline $\begin{array}{l}\text { Independent } \\
\text { variables: } \\
\text { Environment }\end{array}$ & $\begin{array}{l}\text { The environment is one of the } \\
\text { factors that form the character } \\
\text { and nature of a person, the } \\
\text { influence of the environment }\end{array}$ & $\begin{array}{l}\text { a. Level of Faith in the } \\
\text { family } \\
\text { b. The level of faith in the } \\
\text { surrounding community }\end{array}$ & $\begin{array}{l}\text { Likert } \\
1-4 \\
\text { SS, S, KS, TS }\end{array}$ \\
\hline
\end{tabular}




\begin{tabular}{|c|c|c|c|}
\hline Variable & Definition & Indicator & Measuremen \\
\hline & $\begin{array}{l}\text { on the nature and character of } \\
\text { one because of the habit of } \\
\text { undergoing Hidup with the } \\
\text { environment. }\end{array}$ & (Hairudin: 2014) & \\
\hline $\begin{array}{l}\text { Independent } \\
\text { variables: } \\
\text { Zakat } \\
\text { Management } \\
\text { Board } \\
\text { Accountability }\end{array}$ & $\begin{array}{l}\text { The Board of Zakat as the } \\
\text { trustee of Muzakki on Zakat } \\
\text { funds paid through the } \\
\text { institution makes the } \\
\text { management agency obliged } \\
\text { to give accountability, present, } \\
\text { report, disclose all activities } \\
\text { conducted by the institution }\end{array}$ & $\begin{array}{l}\text { a. Accountability } \\
\text { b. Effectiveness } \\
\text { Pangestu \& Jayanto: 2017) }\end{array}$ & $\begin{array}{l}\text { Likert } \\
1-4 \\
\text { SS, S, KS, TS }\end{array}$ \\
\hline $\begin{array}{l}\text { Independent } \\
\text { variable: } \\
\text { socialization of } \\
\text { Zakat } \\
\text { management } \\
\text { Agency }\end{array}$ & $\begin{array}{l}\text { The process of providing } \\
\text { knowledge to the general } \\
\text { public about a thing in the } \\
\text { hope that society will do the } \\
\text { purpose of the agency or } \\
\text { individual in conducting such } \\
\text { socialization activities. }\end{array}$ & $\begin{array}{l}\text { a. Intensity } \\
\text { b. Precise Target } \\
\text { (Sakula: 2015) }\end{array}$ & $\begin{array}{l}\text { Likert } \\
1-4 \\
\text { SS, S, KS, TS }\end{array}$ \\
\hline
\end{tabular}

Table 2. Respondent's descriptive Statistical Data

\begin{tabular}{lll}
\multicolumn{1}{c}{ Description } & Amount & Presentse \\
\hline Gender & & \\
a. Male & 30 & $30 \%$ \\
b. Women & 70 & $70 \%$ \\
Amount & 100 & $100 \%$ \\
Type of Business & & \\
$\quad$ a. Trade & 21 & $21 \%$ \\
b. Manufacture & 70 & $70 \%$ \\
$\quad$ c. Services & 9 & $9 \%$ \\
Amount & 100 & $100 \%$ \\
\hline
\end{tabular}

\section{Company age}

$\begin{array}{lll}\text { a. }<5 \text { years } & 13 & 13 \% \\ \text { b. } 5 \text { years }>x<10 \text { years } & 54 & 54 \% \\ \text { c. }>10 \text { years } & 33 & 33 \% \\ \text { mount } & 100 & 100 \%\end{array}$

Last Education

$\begin{array}{lll}\text { a. SD } & 10 & 10 \% \\ \text { b. SMP/MTs } & 17 & 17 \% \\ \text { c. SMA/SMK/MA } & 56 & 56 \% \\ \text { d. D1/S1 } & 16 & 16 \% \\ \text { mount } & 100 & 100 \%\end{array}$

Source: Processed primary Data, 2019 
Table 3. Variable Descriptive Analysis

\begin{tabular}{|l|c|c|c|c|c|c|}
\hline \multicolumn{1}{|c|}{ Variable } & $\mathrm{n}$ & Min. & Max. & & Mean & Criteria \\
\hline Religiosity & 100 & 20 & 7 & & 17,19 & ST \\
\hline Understanding of zakat & 100 & 18 & 7 & & 14,66 & $\mathrm{~T}$ \\
\hline Income Level & 100 & 12 & 4 & & 8,95 & $\mathrm{~T}$ \\
\hline Environment & 100 & 5 & 16 & & 13,07 & $\mathrm{ST}$ \\
\hline $\begin{array}{l}\text { ZakatManagement Agency } \\
\text { Accountability }\end{array}$ & 100 & 6 & 16 & & 13,64 & $\mathrm{ST}$ \\
\hline $\begin{array}{l}\text { Socialization of } \\
\text { zakatManagement Institute }\end{array}$ & 100 & 2 & 8 & & 6,33 & $\mathrm{~T}$ \\
\hline
\end{tabular}

Source: Processed primary Data, 2019

Table 4. Hypothesis Test Results

\begin{tabular}{|l|r|r|r|r|r|}
\hline & \multicolumn{1}{|c|}{$\begin{array}{l}\text { Original } \\
\text { Sample (O) }\end{array}$} & $\begin{array}{l}\text { Sample } \\
\text { Mean (M) }\end{array}$ & $\begin{array}{l}\text { Standard } \\
\text { Deviation } \\
\text { (STDEV) }\end{array}$ & $\begin{array}{l}\text { T Statistics (| } \\
\text { O/STDEV|) }\end{array}$ & P Values \\
\hline $\begin{array}{l}\text { LPZ Accountability> The } \\
\text { motivation of } \text { Muzakki }\end{array}$ & 0,363 & 0,352 & 0,086 & 4,228 & 0,000 \\
\hline $\begin{array}{l}\text { Environment> Motivation } \\
\text { Muzakki }\end{array}$ & 0,247 & 0,245 & 0,095 & 2,604 & 0,009 \\
\hline $\begin{array}{l}\text { The understanding of Zakat- } \\
\text { > The motivation of Muzakki }\end{array}$ & 0,222 & 0,222 & 0,055 & 4,027 & 0,000 \\
\hline $\begin{array}{l}\text { Religiusitas-> The } \\
\text { motivation of } \text { Muzakki }\end{array}$ & 0,225 & 0,235 & 0,071 & 3,161 & 0,002 \\
\hline $\begin{array}{l}\text { Socialization of LPZ-> The } \\
\text { motivation } \text { Muzakki }\end{array}$ & 0,066 & 0,060 & 0,073 & 0,902 & 0,368 \\
\hline $\begin{array}{l}\text { Income level-> Motivation } \\
\text { Muzakki }\end{array}$ & 0,408 & 0,401 & 0,113 & 3,600 & 0,000 \\
\hline
\end{tabular}

Table 5 Summary of hypothesis testing results

\begin{tabular}{|c|l|c|}
\hline Hypothesis & \multicolumn{1}{|c|}{ Statement } & \multicolumn{1}{|c|}{ Results } \\
\hline $\mathrm{H}_{1}$ & $\begin{array}{l}\text { Religiusitas significantly influence the motivation of Muzakki to pay zakat in } \\
\text { Zakat management Agency }\end{array}$ & $\begin{array}{c}\text { Hypotheses } \\
\text { accepted }\end{array}$ \\
\hline $\mathrm{H}_{2}$ & $\begin{array}{l}\text { Knowledge of Zakat has significant effect on the motivation of Muzakki to } \\
\text { pay zakat in Zakat management Agency }\end{array}$ & $\begin{array}{c}\text { Hypotheses } \\
\text { accepted }\end{array}$ \\
\hline $\mathrm{H}_{3}$ & $\begin{array}{l}\text { The income level significantly affects the motivation of Muzakki to pay zakat } \\
\text { in Zakat management Agency }\end{array}$ & $\begin{array}{c}\text { Hypotheses } \\
\text { accepted }\end{array}$ \\
\hline $\mathrm{H}_{4}$ & $\begin{array}{l}\text { Significant environmental impact on Muzakki 's motivation to pay zakat in } \\
\text { Zakat management Agency }\end{array}$ & $\begin{array}{c}\text { Hypotheses } \\
\text { accepted }\end{array}$ \\
\hline $\mathrm{H}_{5}$ & $\begin{array}{l}\text { Accountability Management Board of Zakat has significant effect on the } \\
\text { motivation Muzakki pay zakat in Zakat management Agency }\end{array}$ & $\begin{array}{c}\text { Hypotheses } \\
\text { accepted }\end{array}$ \\
\hline $\mathrm{H}_{6}$ & $\begin{array}{l}\text { Socialization of Zakat management Agency has no significant effect on the } \\
\text { motivation Muzakki pay zakat in Zakat management Agency }\end{array}$ & $\begin{array}{c}\text { Hypotheses } \\
\text { rejected }\end{array}$ \\
\hline
\end{tabular}




\section{Figure 1 Output Smart PLS}

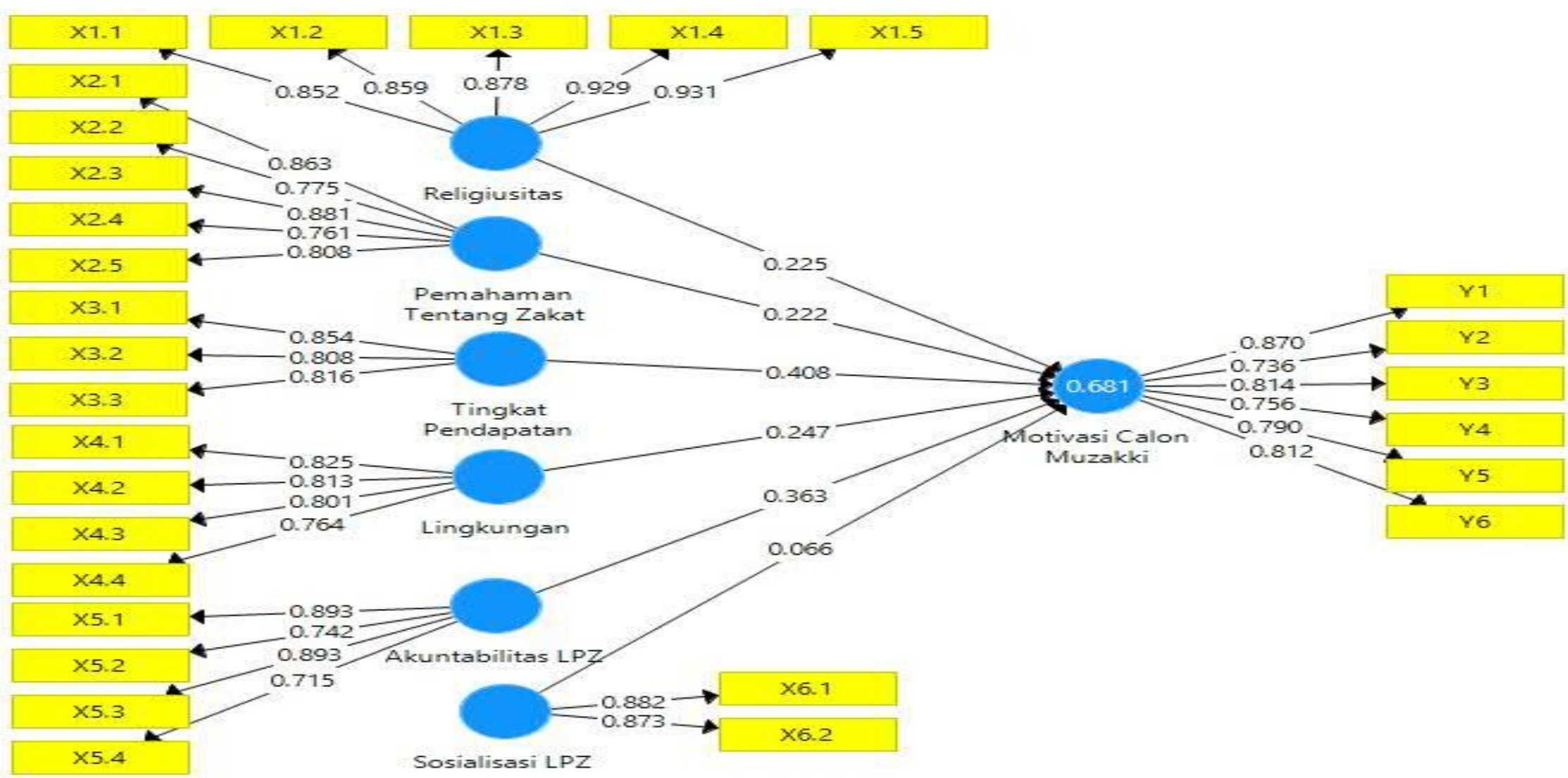

